\title{
Article \\ An Investigation of Rotary Cup Burner Assembly with Three Vehicle-Mounted Cooking Stoves by Numerical Evaluation Method
}

\author{
Yijian Sheng ${ }^{1}$, He Liu ${ }^{1} *{ }^{*}{\text { Limo } \mathrm{He}^{2} \text { and Jun Xiang }}^{2}$ (D) \\ 1 Institute of Quartermaster Engineering and Technology, Beijing 100010, China; jxssyj@sina.com \\ 2 State Key Laboratory of Coal Combustion, School of Energy and Power Engineering, Huazhong University of \\ Science and Technology, Wuhan 430074, China; limo_615@163.com (L.H.); xiangjun@mail.hust.edu.cn (J.X.) \\ * Correspondence: liuhe1980@163.com; Tel.: +86-(010)-6672-7159
}

Citation: Sheng, Y.; Liu, H.; He, L.; Xiang, J. An Investigation of Rotary Cup Burner Assembly with Three Vehicle-Mounted Cooking Stoves by Numerical Evaluation Method. Processes 2022, 10, 186. https:// doi.org/10.3390/pr10020186

Academic Editors: Zhihua Wang and Cherng-Yuan Lin

Received: 8 November 2021

Accepted: 6 January 2022

Published: 18 January 2022

Publisher's Note: MDPI stays neutral with regard to jurisdictional claims in published maps and institutional affiliations.

Copyright: (C) 2022 by the authors. Licensee MDPI, Basel, Switzerland. This article is an open access article distributed under the terms and conditions of the Creative Commons Attribution (CC BY) license (https:// creativecommons.org/licenses/by/ $4.0 /)$.

\begin{abstract}
The adaptability of vehicle-mounted heating systems that include burner and stove remarkably influences the system efficiency, heat flux uniformity, and pollutants emission. In this work, the performance of a rotary cup burner assembly with three different cooking stoves was investigated using ANSYS Fluent software based on five factors of thermal efficiency, heat transfer intensity, heating uniformity, $\mathrm{CO}$ emissions, and flue gas outlet temperature. The Eulerian-Lagrangian method was used to perform the diesel spray, and the shear stress transfer k- $\omega$ turbulence model and the probability density function model were employed to simulate the turbulent combustion. Based on the simulation results, the performance pentagon of the above five factors was constructed to evaluate the comprehensive performance of the new rotary cup burner system. The rotary cup burner had a good performance when it is used in two staple food stoves and a subsidiary food stove. In staple food stove A, its higher furnace increased the heat exchange area of the vessel, while the higher fireboard of staple food stove B caused a higher heat transfer intensity at the bottom of the vessel. However, the higher fireboard also led to higher $\mathrm{CO}$ emissions. In consideration of these two factors, the thermal efficiency of stove A was about 7\% higher than that of stove B. Different from the staple food stove, the furnace of subsidiary food stove $\mathrm{C}$ had better wrapping to the bottom of the boiler so that it had the highest heat transfer intensity. The obtained performance pentagon shows that the comprehensive adaptability performance of stove A was the best and that of stove B was the worst, which is mainly caused by the height of the fireboard and the shape of the vessel. This research guides the optimization of the heating system and promotes the application of the rotary cup burner.
\end{abstract}

Keywords: rotary cup burner; vehicle-mounted cooking stoves; thermal efficiency; heating uniformity; $\mathrm{CO}$ emissions

\section{Introduction}

Fuel oil cooking stove is important vehicle-mounted cooking equipment with high heat density, which can provide daily food security for large groups is mainly composed of a burner and combustion chamber. The combustion characteristics of the fuel oil burner determine the basic thermal performance of the fuel oil cooking stove. At present, the spray characteristics [1-5], flow field characteristics [6-10], flame structure [11-15], and combustion performance [16-21] of fuel oil burners have been extensively studied. As is well known, the overall performance of the fuel oil cooking stove is affected by the combustion characteristics of the burner and also relates to the structure of the combustion chamber. The structure of the combustion chamber, such as the internal baffle setting and the shape of the heating transfer surface usually affect the thermal efficiency, pollutants emission characteristics of the heating system [22-24]. A good heating system needs a suitable matching between the burner and combustion chamber [25]. 
The horizontal spray burner (such as the Riello) is widely used in fuel oil cooking stoves by heating horizontally. When it is used in cooking stoves, especially for the subsidiary food stove, a mismatching exists between the burner and combustion chamber. In the combustion process, the spray flame and the flow of high-temperature flue gas need to rotate 90 degrees in the combustion chamber to heat the vessel because of the horizontal correlation between the flame direction and the heating transfer surface [26]. Thus, this leads to a relatively poor heating uniformity and thermal efficiency of the heating system. In this work, the rotary cup burner, as a new type of fuel oil burner, was investigated. Different from the horizontal spray burner, its flame direction is vertical with the heating transfer surface, which may improve the heating uniformity. Moreover, it has a compact structure so that it can have an important role in the vehicle-mounted heating system.

According to the experiment results, we also found that the structure of the combustion chamber and stove remarkably influence the system efficiency, heating uniformity, and pollutants emission when the rotary cup burner is assembled with different vehiclemounted cooking stoves. Therefore, in order to promote the application of this burner, the adaptability investigation with different stoves is very important. Until now, there are few studies in the literature that reported relevant research.

Furthermore, different from the solo performance factor, the performance analysis of rotary cup burner assembly with three vehicle-mounted cooking stoves was conducted by comparing with five factors (thermal efficiency, heat transfer intensity, heating uniformity, $\mathrm{CO}$ emission, and flue gas temperature) in this work. The performance pentagon of three stoves at different powers was drawn, which can clearly compare the results. The investigation results can significantly contribute to the design of this kind of heating system.

At present, the atomization performance of rotary cup atomizers has been widely studied [27-31], but there is no in-depth study on the combustion and heat transfer process [32]. In order to analyze whether the rotary cup burner is suitable for the cooking stoves (one subsidiary food stove and two staple food stoves), the steady-state numerical simulation of fuel oil cooking stoves using three different combustion chamber structures was carried out, and the comprehensive performance of stove was compared and analyzed based on multiple characteristics. The key structural parameters affecting the performance were obtained from the comparison of different structures.

\section{Numerical Simulation Process}

\subsection{Model and Grid}

Simplified 3D models were established according to the actual size of the rotary cup burner and the cooking stove. The rotary cup burner is cylindrical, with a diameter of $160 \mathrm{~mm}$ and a height of $59 \mathrm{~mm}$. A coaxial motor and fan are connected below. Air is supplied by the fan into the rotary cup burner from below, and light diesel oil is injected into the rotary cup from below to above. The combustion chamber and the vessel constitute an integrated structure, which is divided into staple food stove A, staple food stove B, and subsidiary food stove $C$. The structure is shown in Figures 1 and 2, and the rotary cup burner is installed at the bottom opening. In order to facilitate the simulation setting and calculation, the fan part was simplified, and the air inlet was simplified to a mass flow inlet with a certain swirl fraction. 


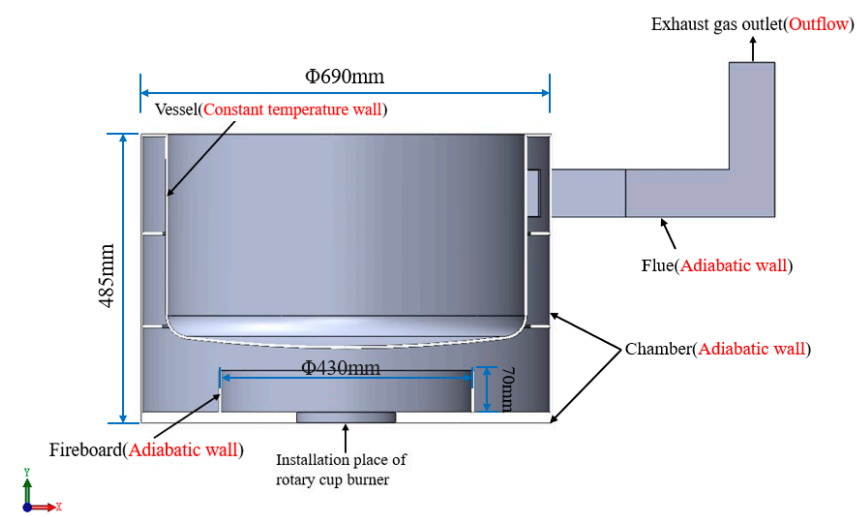

(a)

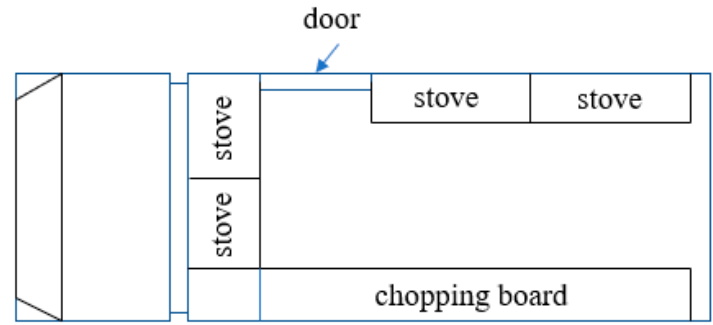

(b)

Figure 1. Schematic diagram of stove A's combustion chamber: (a) 3D model and boundary conditions; (b) stove's localization in the vehicle.

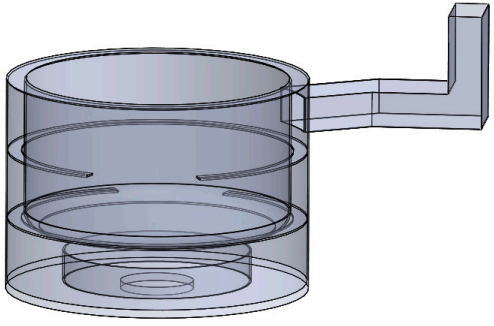

(a)

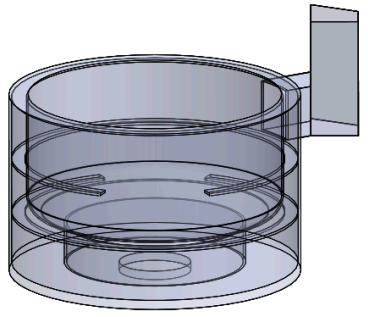

(b)

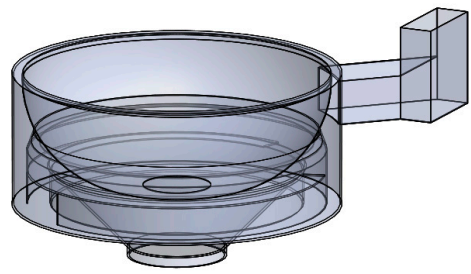

(c)

Figure 2. The 3D models of stove chambers: (a) staple food stove A; (b) staple food stove B; (c) subsidiary food stove $\mathrm{C}$.

Since the structure of the whole computational domain was relatively complex, and there were many fine structures inside the rotary cup burner, the unstructured grids attribute with strong adaptability were used to mesh, and local grid refinement was used for rotary cup areas. 


\subsection{Numerical Methods}

\subsubsection{Governing Equations}

The equation for conservation of mass can be written as

$$
\frac{\partial \rho}{\partial t}+\nabla(\rho \vec{v})=S_{m}
$$

and the momentum conservation equation can be written as

$$
\frac{\partial}{\partial t}(\rho \vec{v})+\nabla(\rho \vec{v} \vec{v})=-\nabla p+\nabla \overline{\bar{\tau}}+\rho \vec{g}+\vec{F},
$$

where $S_{m}$ is the mass added to the continuous phase from the discrete phase, $p$ is the static pressure, $\overline{\bar{\tau}}$ is the stress tensor, $\rho \vec{g}$ is the gravitational body force, and $\vec{F}$ is the external body forces.

For the non-premixed combustion model used, the energy equation can be written in the form of total enthalpy as follows:

$$
\frac{\partial}{\partial t}(\rho H)+\nabla(\rho \vec{v} H)=\nabla\left(\frac{k_{e f f}}{C_{p}} \nabla H\right)+S_{h}
$$

where $k_{e f f}$ is the effective conductivity, $S_{h}$ is the volumetric heat source, and $H$ is total enthalpy, which is defined as

$$
H=\sum_{j} Y_{j} H_{j}
$$

where $Y_{j}$ is the mass fraction of species $j$ and

$$
H_{j}=\int_{T_{r e f, j}}^{T} c_{p, j} d T+h_{j}^{0}\left(T_{r e f, j}\right),
$$

where $h_{j}^{0}\left(T_{r e f, j}\right)$ is the formation enthalpy of species $j$ at a reference temperature $T_{r e f, j}$.

\subsubsection{Turbulence Model}

Due to the existence of the high-speed rotating cup in the burner, the multiple reference frame model was used to simulate the influence of rotation. When meshing, the region near the rotary cup was cut into a separate domain, and the rotation speed was given. In addition, the shear stress transfer $k-\omega$ turbulence model, which is commonly used to simulate the flow of rotating machinery, was selected for turbulence calculation. This model adjusts the turbulent viscosity considering the transport characteristics of turbulent shear stress so that it can give full play to the respective advantages of the $k-\varepsilon$ model and $k-\omega$ model in dealing with the near-wall area and far flow field and can obtain more accurate simulation results. Its transport equations are as follows:

$$
\begin{gathered}
\frac{\partial k}{\partial t}+u_{i} \frac{\partial k}{\partial x_{i}}=\frac{\partial}{\partial x_{j}}\left[\left(v+\sigma_{k} v_{t}\right) \frac{\partial k}{\partial x_{j}}\right]+\widetilde{P}_{k}-k \omega \beta^{*}+S_{k} \\
\frac{\partial \omega}{\partial t}+u_{i} \frac{\partial \omega}{\partial x_{i}}=\frac{\partial}{\partial x_{j}}\left[\left(v+\sigma_{k} v_{t}\right) \frac{\partial \omega}{\partial x_{j}}\right]+0.44 S^{2}-\beta \omega^{2}+2\left(1-F_{1}\right) \sigma_{\omega 2} \frac{1}{\omega} \frac{\partial k}{\partial x_{j}} \frac{\partial \omega}{\partial x_{j}}+S_{\omega},
\end{gathered}
$$

where $v_{t}$ is the turbulent viscosity coefficient, $\sigma_{k}$ and $\sigma_{\omega}$ are the Prandtl number of $k$, and $\omega$, $F_{1}$ is a function defined as

$$
F_{1}=\tan \Phi_{1}^{4}
$$

and

$$
\Phi_{1}=\min \left[\max \left(\frac{\sqrt{k}}{\beta^{*} \omega y}, \frac{500 v}{y^{2} \omega}\right), \frac{4 \rho \sigma_{\omega 2} k}{C D_{k \omega} y^{2}}\right]
$$




$$
\begin{gathered}
C D_{k \omega}=\max \left[2 \rho \sigma_{\omega 2} \frac{1}{\omega} \frac{\partial k}{\partial x_{j}} \frac{\partial \omega}{\partial x_{j}}, 10^{-10}\right], \\
\widetilde{P}_{k}=\min \left[v_{t} \frac{\partial u_{i}}{\partial x_{j}}\left(\frac{\partial u_{i}}{\partial x_{j}}+\frac{\partial u_{j}}{\partial x_{i}}\right), 10 \rho k \omega \beta^{*}\right],
\end{gathered}
$$

and the constants in the equations are as follows:

$$
\beta^{*}=0.09, \sigma_{\omega 2}=0.856 .
$$

\subsubsection{Radiation Model}

As the discrete ordinate (DO) model is applicable in the whole optical thickness range, and the gas radiation effect of triatomic molecules such as $\mathrm{CO}_{2}$ and $\mathrm{H}_{2} \mathrm{O}$ in combustion products can be considered, the DO model was selected as the radiation model. Additionally, the absorption coefficients of gases were calculated by the weighted-sum-of-gray-gases model (WSGGM).

\subsubsection{Discrete Phase Model}

The discrete phase model (Eulerian-Lagrangian) was selected to spray diesel droplets into the fluid domain for coupling calculation. The fluid phase was treated as a continuum by solving the Navier-Stokes equations, while the dispersed phase was solved by tracking a large number of droplets. The trajectory of the droplet was predicted by calculating the force balance of the droplet, and the equation can be written as

$$
\frac{d \overrightarrow{u_{p}}}{d t}=\frac{18 \mu}{\rho_{p} d_{p}^{2}} \frac{C_{d} R e}{24}\left(\vec{u}-\overrightarrow{u_{p}}\right)+\frac{\vec{g}\left(\rho_{p}-\rho\right)}{\rho_{p}},
$$

where $\vec{u}$ and $\overrightarrow{u_{p}}$ are the velocities of the fluid phase and droplet, $\rho$ and $\rho_{p}$ are the densities of the fluid phase and droplet, $\mu$ is the molecular viscosity of the fluid, $d_{p}$ is the particle diameter, $C_{d}$ is the drag coefficient given by Morsi and Alexander [33], and $R e$ is the relative Reynolds number defined as

$$
\operatorname{Re} \equiv \frac{\rho d_{p}\left|\overrightarrow{u_{p}}-\vec{u}\right|}{\mu},
$$

When the droplet temperature is less than the vaporization temperature, the inert heating law is applied, and a simple heat balance is used to relate the particle temperature as follows:

$$
m_{p} c_{p} \frac{d T_{p}}{d t}=h A_{p}\left(T_{\infty}-T_{p}\right)+\varepsilon_{p} A_{p} \sigma\left(\theta_{R}^{4}-T_{p}^{4}\right),
$$

When the temperature of the droplet reaches the vaporization temperature, the droplet vaporization law is applied and continues until the droplet reaches the boiling point, or until the droplet's volatile fraction is completely consumed. Following the work of Miller [34] and Sazhin [35], the mass transfer and heat transfer during the droplet vaporization law can be expressed as

$$
\frac{d m_{p}}{d t}=k_{c} A_{\rho} \ln \left(1+B_{m}\right)
$$

and

$$
m_{p} c_{p} \frac{d T_{p}}{d t}=h A_{p}\left(T_{\infty}-T_{p}\right)-\frac{d m_{p}}{d t} h_{f g}+\varepsilon_{p} A_{p} \sigma\left(\theta_{R}^{4}-T_{p}^{4}\right),
$$

where $h_{f g}$ is the latent heat, $k_{c}$ is the mass transfer coefficient, and $B_{m}$ is the Spalding mass number given by

$$
B_{m}=\frac{Y_{i, s} Y_{i, \infty}}{1-Y_{i, s}}
$$


Additionally, when the temperature of the droplet is above the boiling temperature, the droplet boiling law is applied, and the droplet is assumed to stay at a constant temperature. The equation related to the boiling rate of the droplet can be expressed as

$$
\frac{d\left(d_{p}\right)}{d t}=\frac{2}{\rho_{p} h_{f g}}\left[\frac{2 k_{\infty}\left(1+0.23 \sqrt{R e_{d}}\right)}{d_{p}}\left(T_{\infty}-T_{p}\right)+\varepsilon_{p} \sigma\left(\theta_{R}^{4}-T_{p}^{4}\right)\right] .
$$

where $k_{\infty}$ is the thermal conductivity of the gas.

Since the actual fuel injection process of the rotary cup burner is a low-pressure injection process, the atomization and evaporation of oil droplets are mainly carried out in the rotary cup, whereas the fuel injection process was simplified as a solid cone spray process at the actual nozzle position. In the numerical calculation process, the discrete phase was iterated with an interval of 20 iterations of the continuous phase, and the discrete random walk model was employed.

\subsubsection{Combustion Model}

As for the combustion model, the probability density function (PDF) model in nonpremixed combustion was used. This model does not need to artificially define the combustion reaction mechanism but uses probability density function to analyze the turbulent effect in the combustion process. In this method, only one or two conservation scalar transport equations need to be solved, and then the concentration of each component is derived from the predicted mixing fraction distribution, which is suitable for the simulation of turbulent diffusion flame.

\subsection{Boundary Conditions}

The combustion of the rotary cup burner at $20 \mathrm{~kW}, 30 \mathrm{~kW}, 40 \mathrm{~kW}$ power was simulated at the excess air coefficient of 1.035. The mass flow inlet boundary condition was used for air inlet, and the turbulence was specified by turbulence intensity $I_{t}$ and hydraulic diameter $d$ as follows:

$$
\begin{aligned}
I_{t}=\frac{u^{\prime}}{u_{\text {avg }}} & =0.16(R e)^{-1 / 8}, \\
d & =\frac{4 A}{P},
\end{aligned}
$$

where $u^{\prime}$ is the root-mean-square of the velocity fluctuations, $u_{\text {avg }}$ is the mean flow velocity, $A$ is the cross-sectional area of the inlet, and $P$ is the cross-sectional perimeter of the inlet.

The non-slip boundary condition was used for all walls, then a constant temperature of $373 \mathrm{~K}$ was set for the vessel wall as its chamber is covered with thick aluminum silicate cotton for a good insulation effect. All walls were defined as adiabatic walls except the vessel wall. Depending on the wall material, the emissivity of the vessel wall and other walls were set to 0.8 and 0.6 , respectively. The boundary conditions at $40 \mathrm{~kW}$ are shown in Table 1.

Table 1. Boundary conditions at $40 \mathrm{~kW}$.

\begin{tabular}{cc}
\hline Boundary Type & BC Setting \\
\hline Air inlet & Mass-flow-inlet \\
& $0.0142 \mathrm{~kg} / \mathrm{s}$ \\
\hline Fuel inlet & Light diesel fuel $\left(\mathrm{C}_{12} \mathrm{H}_{23}\right)$ \\
& $0.00094 \mathrm{~kg} / \mathrm{s}$ \\
outlet & Solid-cone injection \\
\hline Combustion chamber wall & outflow \\
\hline Vessel wall & Adiabatic wall \\
\hline
\end{tabular}




\subsection{Grid Independence and Verification of Numerical Model}

To determine the number of grids, a grid independence analysis of stove B was carried out. Three different numbers of grids were meshed by the same method, which had 2,365,854 cells, 4,331,924 cells, and 7,573,556 cells. Figure 3 shows the temperature distribution of $Z$ axis on the $Y=270 \mathrm{~mm}$ plane under the three grids. It can be seen that the temperature distribution curve of 7,573,556 cells is close to that of 4,331,924 cells, while that of $2,365,854$ cells is quite different from these two. To ensure grid independence and reduce the computing resource required, the grid of 4,331,924 cells was used for subsequent calculations. The final grids of the three stoves are presented in Figure 4 , and the grid numbers of stove A and stove C obtained by this method are 4,309,298 and $2,813,561$, respectively.

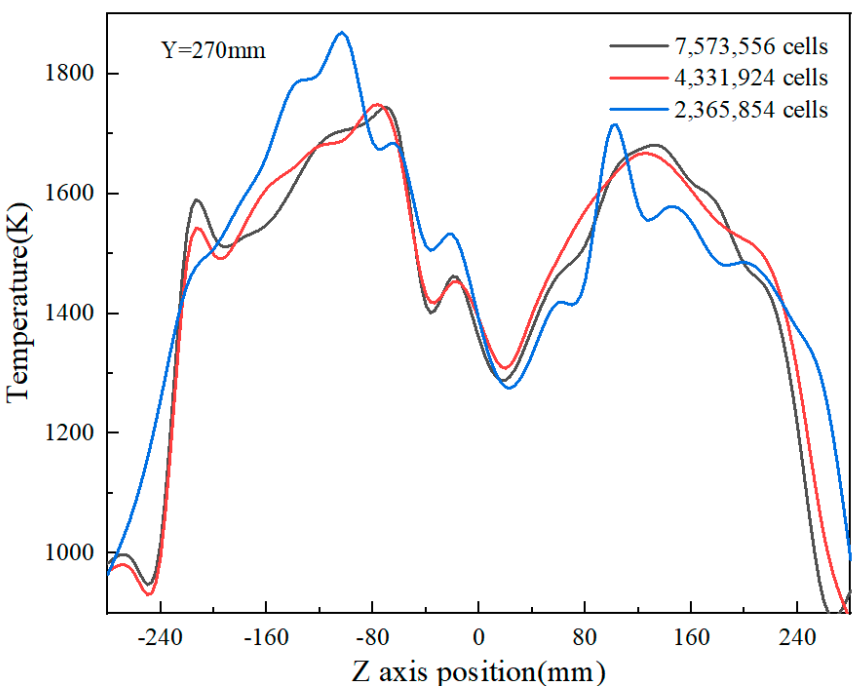

Figure 3. Temperature distribution on $\mathrm{Z}$ axis of stove $\mathrm{B}$ at $40 \mathrm{~kW}$.

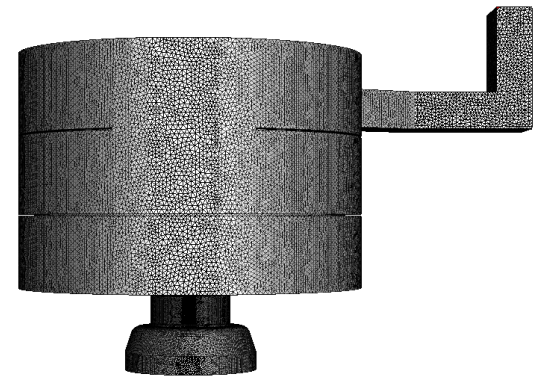

(a)

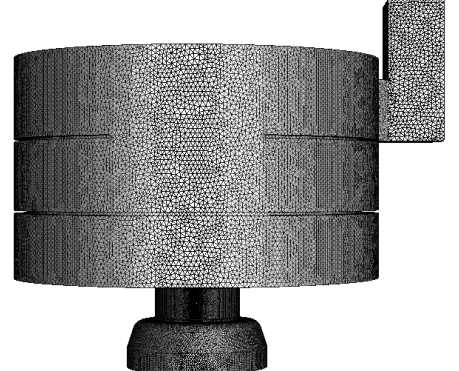

(b)

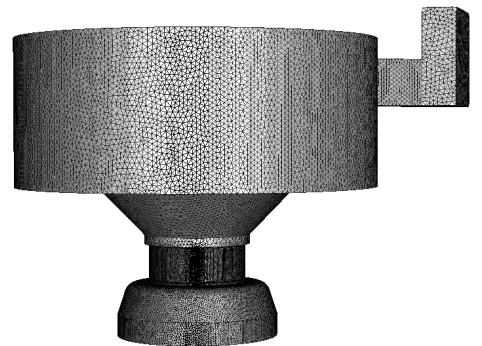

(c)

Figure 4. Grids of stove chambers: (a) staple food stove A; (b) staple food stove B, (c) subsidiary food stove $\mathrm{C}$.

In order to verify the accuracy of the numerical method, the vessel of the stove was removed, and the temperature at the bottom of stove $C$ was measured with an infrared 
thermometer gun and compared with simulated results. The setting of measuring points and the comparison of experimental and simulated results are shown in Figure 5. The simulated temperature is slightly higher than the experiment, which is partly due to the assumption of an adiabatic wall boundary condition, while the overall trends of experimental and simulated results are matched. Therefore, it can be considered that the numerical method adopted is reasonable.

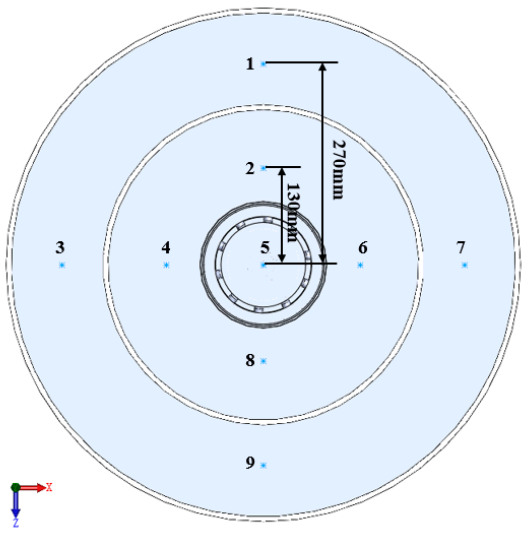

(a)

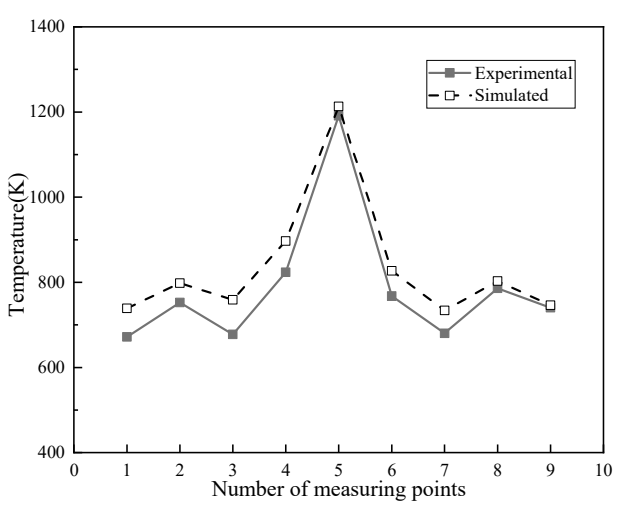

(b)

Figure 5. Validation of numerical methods: (a) measuring points setting; (b) comparison of experimental and simulated results.

\section{Results and Discussion}

\subsection{Analysis of Thermal Efficiency}

The thermal efficiency of the three kinds of fuel oil cooking stoves obtained by simulation under different power is shown in Figure 6. In this research, thermal efficiency is defined as the percentage of vessel heat absorption to fuel heat release. The simulation results show that the thermal efficiency of the cooking stoves assembled by the rotary cup burner is close. The thermal efficiency of the staple food stove A is the highest, followed by the subsidiary food stove, and the staple food stove B is the lowest. The thermal efficiency under different power does not change significantly.

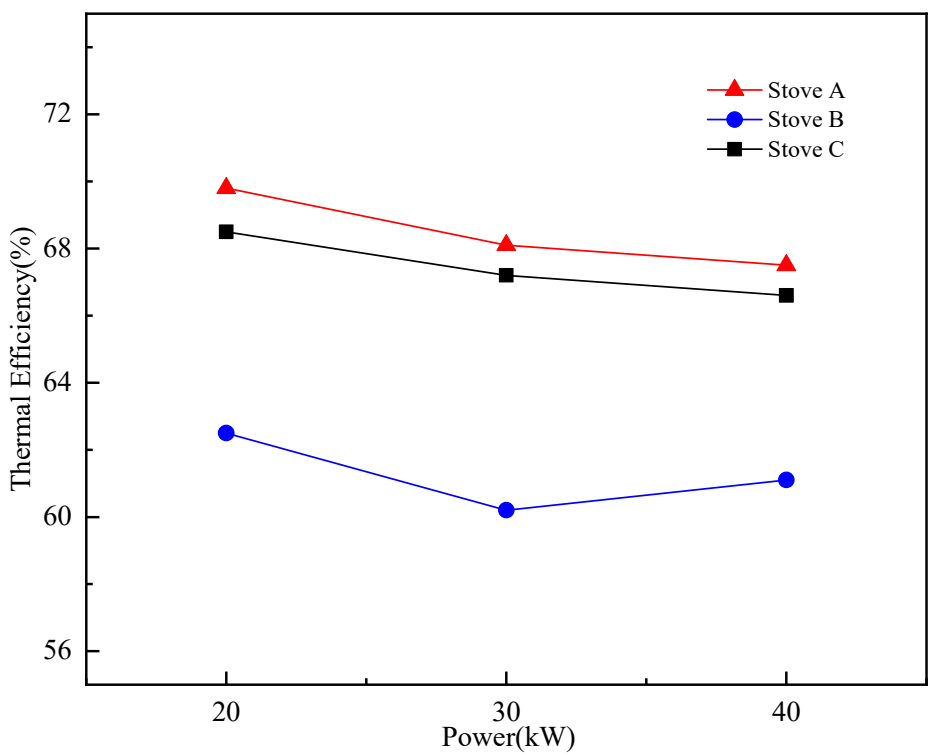

Figure 6. Thermal efficiency of the three stoves at different powers. 
For open cooking stoves, an increase in power is proportional to an increase in heat loss, which leads to a decrease in thermal efficiency. However, the studied fuel oil cooking stove, the closed combustion chamber structure, and the outer insulation layer can greatly reduce heat loss, leading to thermal efficiency under different power, which does not change significantly.

The structure of stove A and stove B are similar, and the main difference is the vessel depth and the height of the fireboard. The vessel depth of stove A is about $60 \mathrm{~mm}$ higher than that of the comprehensive support vehicle, which makes the vessel side of stove A have a larger heat transfer area with the high-temperature flue gas, to improve the thermal efficiency. The height of stove B fireboard is higher than that of stove A, which form a narrow gap with the bottom of the vessel so that the high-temperature flue gas on both sides of the central flame forms a reflex area in the middle of the fireboard; it also strengthens the central area heat transfer with the strongest heat flux and is also conducive to the improvement of the thermal efficiency.

Stove $C$ is equipped with a wok, and the shape of the wok and the structure of the combustion chamber are disparate from stoves A and B, resulting in a smaller space in the combustion chamber. The guiding plate and the combustion chamber form a multi-layer flue gas flow area. Although the residence time of the flue gas in the combustion chamber is increased, the heat transfer process between the flue gas and the bottom of the boiler does not increase, and the improvement in the thermal efficiency is not apparent for stoves $\mathrm{A}$ and $\mathrm{B}$. On the other hand, the cone sleeve of stove $\mathrm{C}$ provides high-temperature flue gas, which forms reflux on both sides of the central area and also acts as a radiation source for the radiative heat transfer of the boiler bottom, thus improving the thermal efficiency.

\subsection{Analysis of Heat Transfer Intensity}

The heat absorption process of the vessel is mainly carried out by convection and radiation heat transfer. Nusselt number is a dimensionless number in fluid mechanics and heat transfer, which can characterize the intensity of convective heat transfer. The formula is

$$
\mathrm{Nu}=\mathrm{hL} / \lambda,
$$

where $\mathrm{h}$ is the convective heat transfer coefficient between the fluid and the solid surface, $\mathrm{L}$ is the characteristic length of the heat transfer surface, and $\lambda$ is the thermal conductivity of the fluid.

Since there is no dimensionless number that reflects the radiation heat transfer intensity, the average Nusselt number is divided into convective heat transfer ratio, which is denoted as I, and the total heat transfer intensity of the three stoves was compared and analyzed. The heat transfer balance of simulation results was verified and is presented in Table 2 before heat transfer analysis. All the errors are less than $5 \%$, and heat can be considerably conserved.

Table 2. Heat flux report at $40 \mathrm{~kW}$.

\begin{tabular}{cccc}
\hline & Stove A & Stove B & Stove C \\
\hline Heat input $(\mathrm{W})$ & $40,388.03$ & $39,872.02$ & $40,751.97$ \\
Net heat $(\mathrm{W})$ & -633.43 & 679.14 & -12.51 \\
Error & $1.57 \%$ & $1.70 \%$ & $0.03 \%$ \\
\hline
\end{tabular}

The temperature distribution of the central section and the I values in the bottom of the vessel of three fuel oil cooking stoves were obtained by simulation, as shown in Figures 7 and 8 . The simulation results show that the proportion of radiation heat transfer of vessels is about $50 \%$. Additionally, the I values of the three kinds of fuel oil cooking stoves increase with the increase in power, that is, the total heat transfer intensity increases with the increase in power. This is because the flue gas velocity and temperature are improved under high power, and the total heat transfer intensity is increased. The heat 
transfer intensity of stove $C$ is significantly higher than that of stoves A and B, due to the vessel shape and the combustion chamber structure difference of the three stoves. The vessel of stove $C$ is a wok, in comparison with the others, making the proportion of flame erosion area of the vessel to be larger and to have a better-wrapped degree. At the same time, the cone sleeve of stove $C$ increases the radiation heat transfer to the bottom of the vessel, making the total heat transfer intensity become the highest. For the two staple food stoves, the recirculation of flue gas inside the fireboard of stove B makes the part have a larger Nusselt number, and its lower combustion chamber height reduces the proportion of the low Nusselt number area on the vessel side, thus making its convective heat transfer intensity higher than that of stove $\mathrm{A}$ and also increasing its total heat transfer intensity.

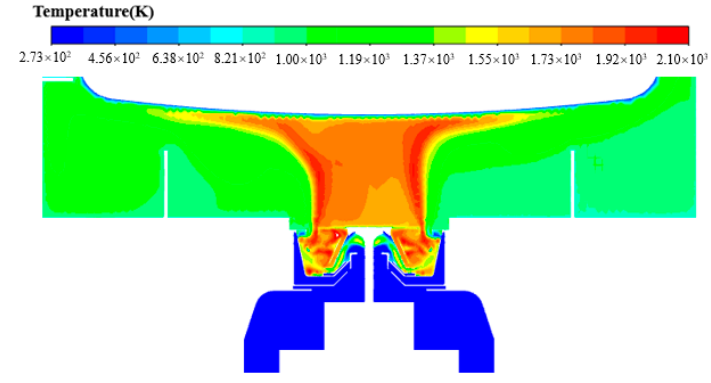

(a)

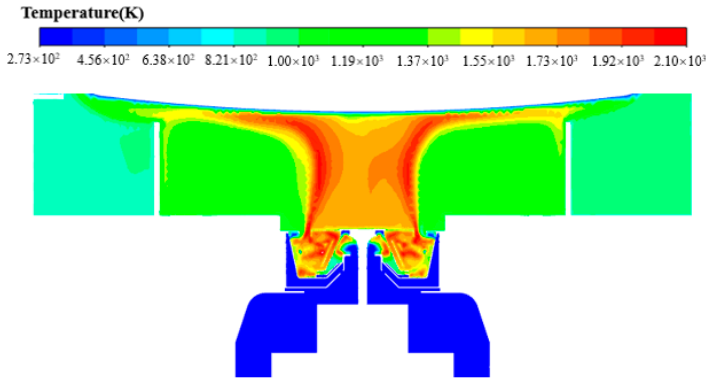

(b)

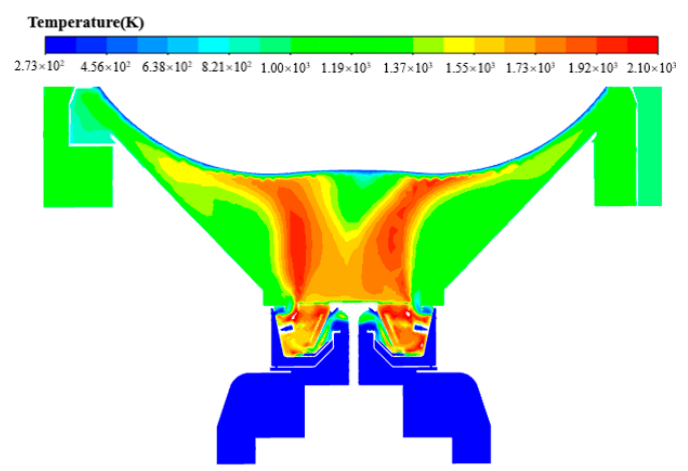

(c)

Figure 7. Temperature contours in the central section of the three stoves at $40 \mathrm{~kW}$ : (a) staple food stove A; (b) staple food stove B; (c) subsidiary food stove C.

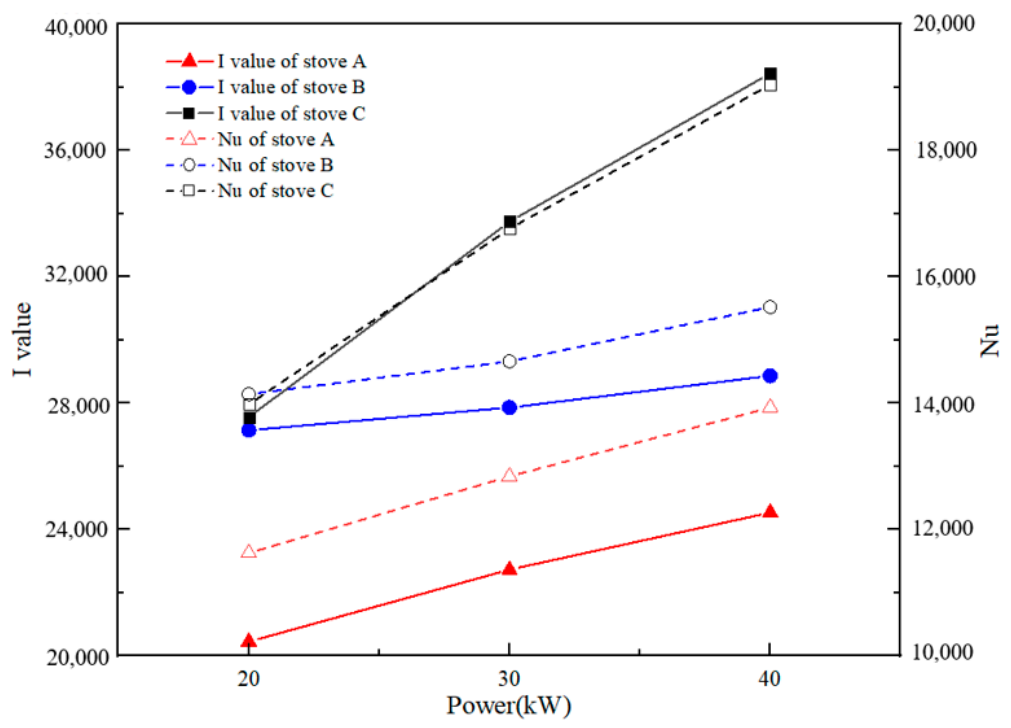

Figure 8. Nu number and I value of the three stoves at different powers. 


\subsection{Analysis of Heat Flow Uniformity of Vessel}

The heat flux uniformity of the vessel affects the efficiency of the cooking work. Therefore, the uniformity index $\gamma$ of the heat flux of the vessel is calculated to evaluate the heat flux uniformity as follows:

$$
\gamma=1-\frac{\sum_{i=1}^{n}\left[\left(\left|\phi_{i}-\bar{\phi}\right|\right) A_{i}\right]}{2|\bar{\phi}| \sum_{i=1}^{n} A_{i}}
$$

where $i$ is the number of grid sequences, $\phi$ is the heat flux of a grid surface, $\bar{\phi}$ is the average heat flux of all grid surfaces, and $A_{i}$ is the area of a certain grid surface. The heat flux uniformity characterizes the variation of heat flux over a given surface.

The heat flux uniformity index of the three kinds of stoves under different power is shown in Figure 9. From Figure 9, stove A presented the best heat flux uniformity, whereas the heat flux uniformity of the other two stoves is slightly lower. At the same time, the heat flux uniformity of the stove decreases with the rotary cup burner power increase.

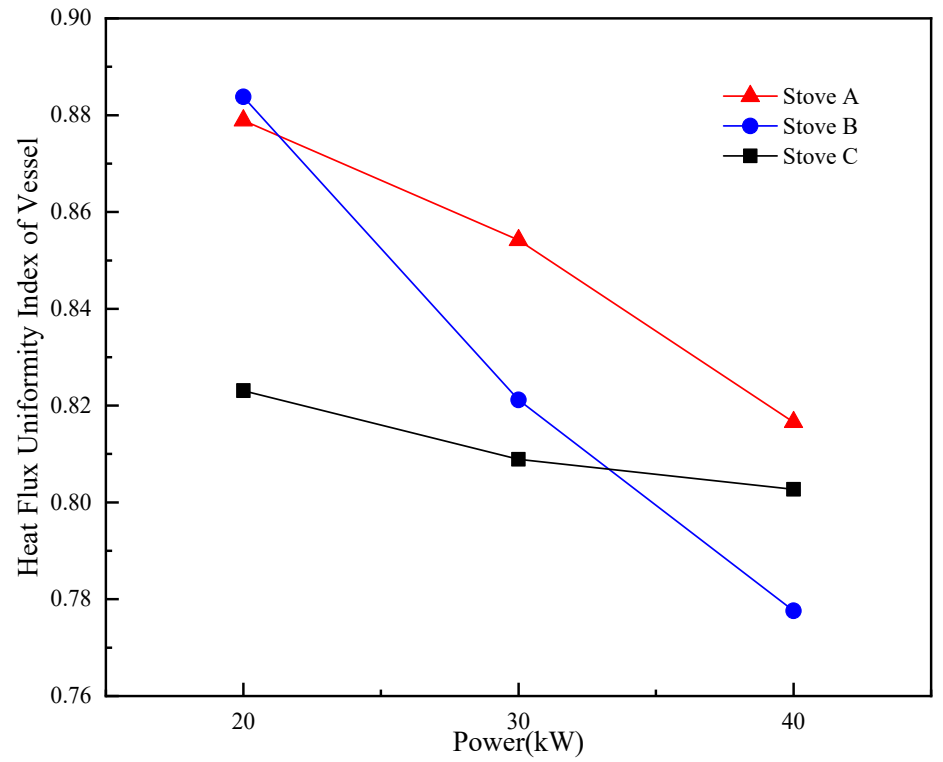

Figure 9. Heat flux uniformity index of the three stoves at different power rates.

Figure 10 shows the heat flux distribution of stoves A, B, and C under three powers. It can be observed that the power has a significant influence on the heat flux intensity of the vessel center. The increase in power correlates to the higher local heat flux intensity in the central area of the vessel bottom, and the change of heat flux intensity in other parts of the pot is relatively small, so the overall heat flux uniformity index decreases. The heat flux uniformity of stove $C$ is less affected by the power change, because the area ratio of cooking vessel washed by flame is large, and the power change only affects the overall heat flux intensity, which has little effect on the overall heat flux uniformity.

The heat flux uniformity of stove A is better than that of stove B because the hightemperature flue gas on both sides of the central flame forms a recirculation zone in the middle of the fireboard, which strengthens the heat transfer in the central area of the vessel bottom and also causes a greater difference in the heat flux intensity of the whole vessel, resulting in a decrease in the heat flux uniformity index; the streamlines at $40 \mathrm{~kW}$ shown in Figure 11 also confirm this finding. 


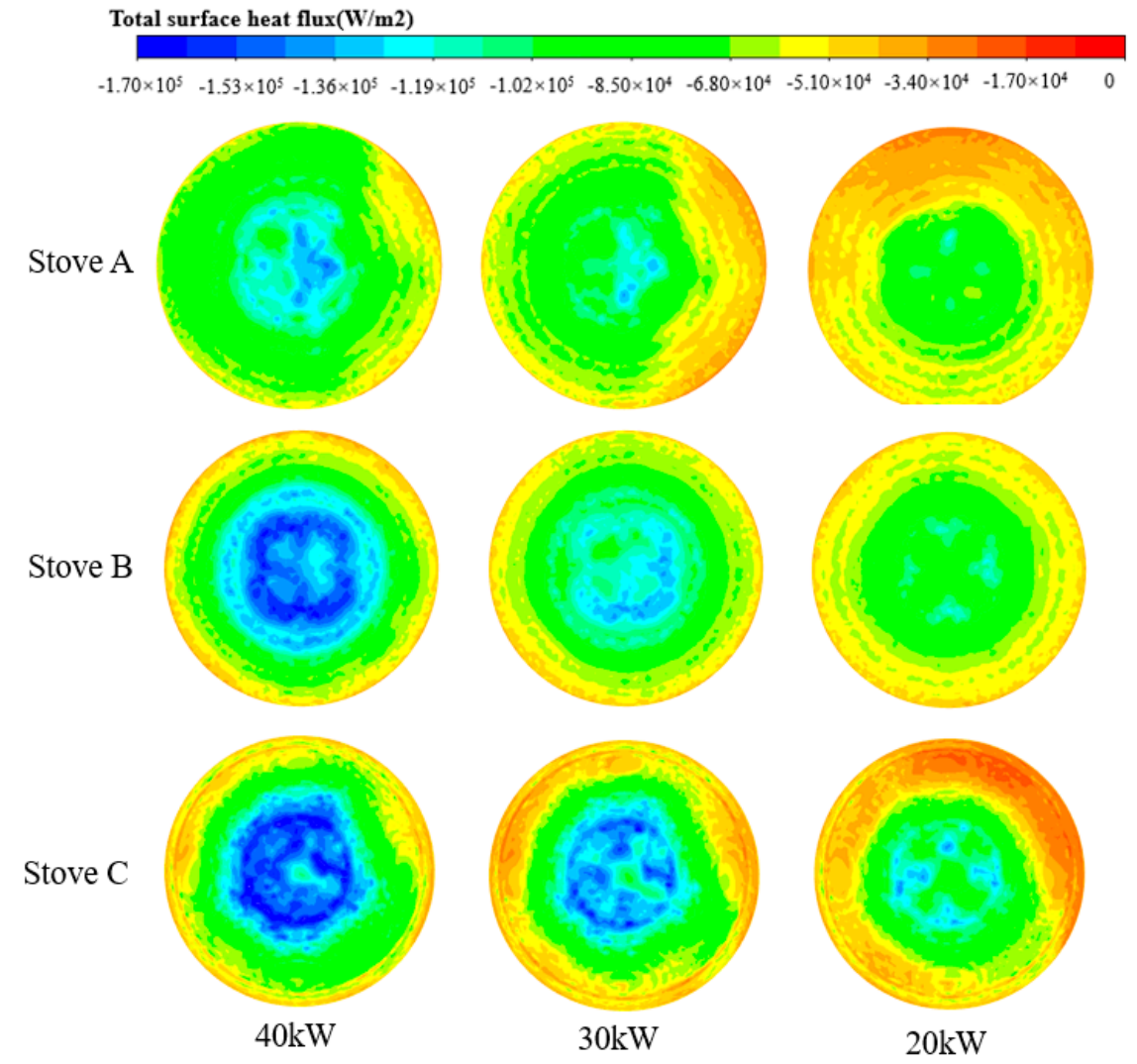

Figure 10. Total heat flux contour of the three stoves at different power rates.

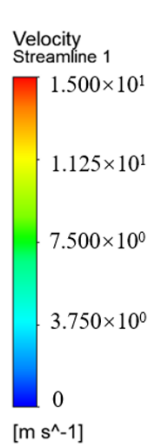

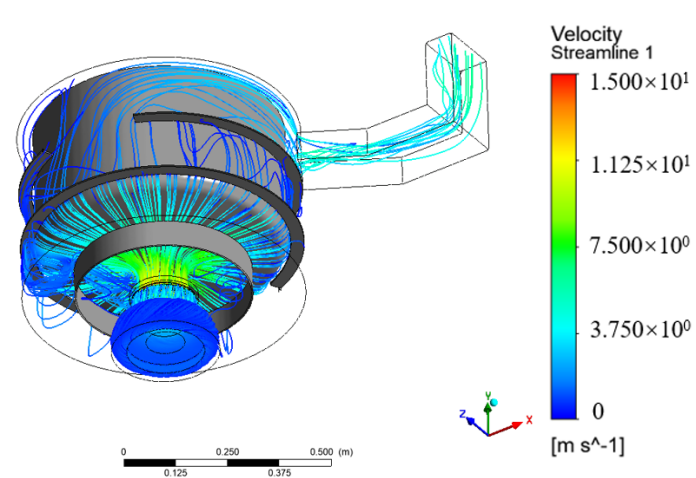

(a)

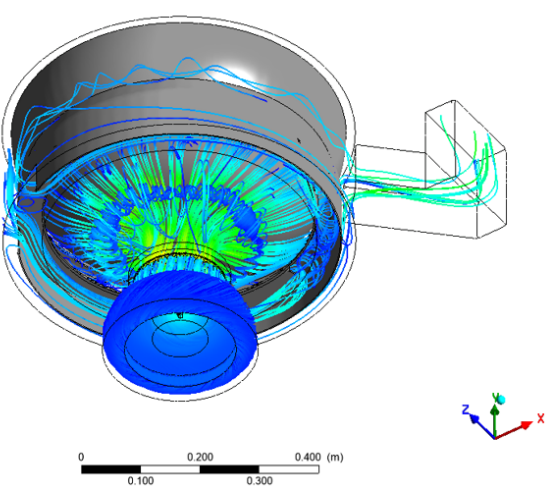

(c)

Figure 11. Streamline of the three stoves at $40 \mathrm{~kW}$ : (a) staple food stove A; (b) staple food stove B, (c) subsidiary food stove $\mathrm{C}$. 


\subsection{Analysis of $\mathrm{CO}$ Emissions}

The CO mass fraction (flue outlet) of the three stoves at different power levels is shown in Figure 12. Comprehensively, the $\mathrm{CO}$ emissions of the stoves decrease with a decrease in power. The $\mathrm{CO}$ emissions of stove B significantly surpassed that of other assembled stoves over different power levels, this is because the space composed of the fireboard, and the vessel is near the closure, which is not conducive to the full combustion of fuel.

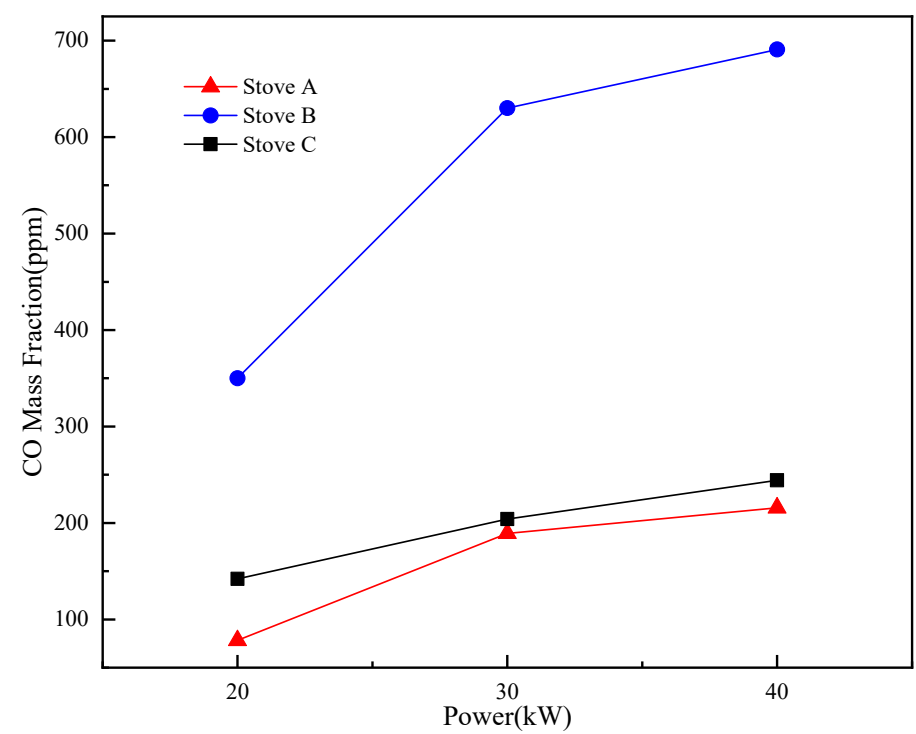

Figure 12. CO mass fraction of the three stoves at different power rates.

Figure 13 shows the $\mathrm{CO}$ mass fraction distribution of the central section of three stoves at three power rates. With the decrease in power, the overall $\mathrm{CO}$ concentration in the combustion chamber decreases, indicating that the incomplete combustion of fuel increases with the increase in power. However, the rotating speed of the rotary cup is accelerated with increasing power, which enhances the disturbance and promotes the mixing of fuel and air to a certain extent; the limited degree of promotion, which cannot completely offset the trend of uneven mixing of fuel and air caused by the increase in the fuel flow, increases incomplete combustion of fuel and, therefore, $\mathrm{CO}$ mass fraction at the outlet of the flue.

\subsection{Analysis of Flue Gas Temperature at the Outlet of the Model}

Considering the heat loss of the stove, exhaust gas heat loss is the most important way of heat loss, and therefore, exhaust temperature directly affects and reflects the thermal efficiency of the stove. The flue was simplified in the modeling process, and the flue gas temperature at the outlet of the model was used as an index to analyze the heat loss of the exhaust gas. The outlet flue gas temperature of the three stoves at different power levels is shown in Figure 10. The results show that the outlet flue gas temperatures of the three models of fuel oil cooking stoves are all above $900 \mathrm{~K}$, which is caused by the set adiabatic wall conditions and by ignoring the heat loss of the combustion chamber and the outer wall of the flue. In addition, the actual fuel oil cooking stove flue length is much longer than the simplified model flue length, which makes the simulation temperature results higher than the actual.

In Figure 14, the outlet flue gas temperature of stove A and stove C changes slightly with power, while the outlet flue gas temperature of stove B decreases significantly with the increase in power. It is speculated that this result is caused by the incomplete combustion degree of fuel. The change in CO mass fraction in Section 3.4 shows that the CO mass fraction of stove $B$ is significantly higher than that of the other two stoves, and the change in $\mathrm{CO}$ mass fraction is more significant, compared with the change in power level, signifying that the incomplete combustion degree of stove B is higher, and the change exhibited by 
incomplete combustion degree is notable with change in power level, resulting in a large change in the flue gas temperature at the model outlet under different power levels.

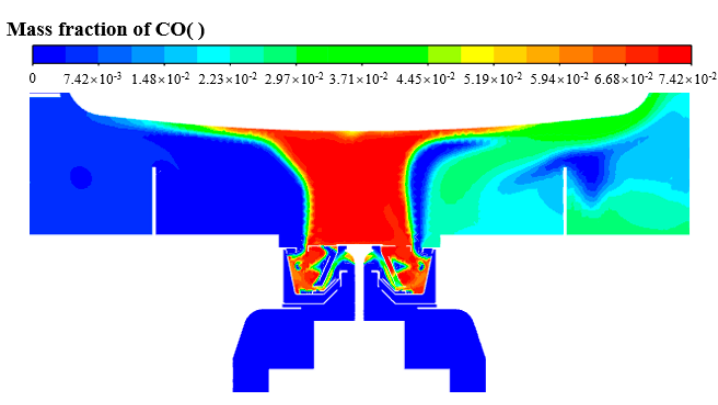

(a)
Mass fraction of $\mathrm{CO}()$

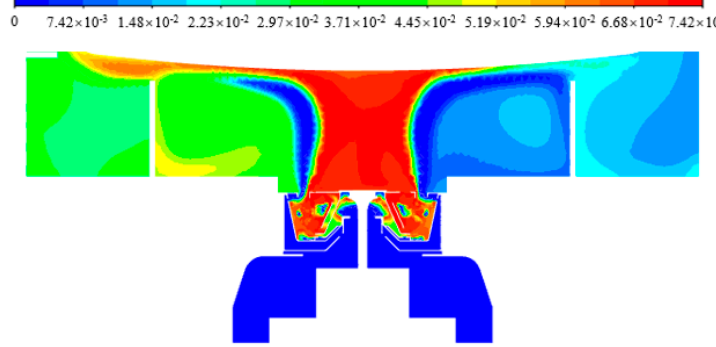

(b)

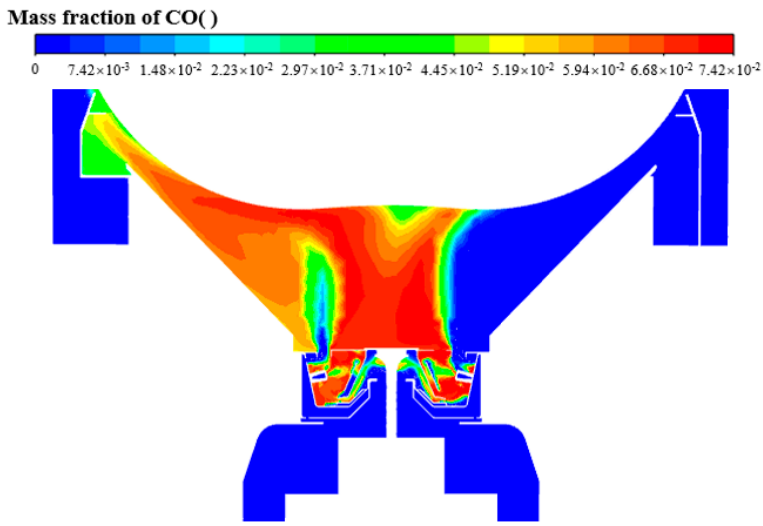

(c)

Figure 13. CO mass fraction contours of the central section of the three stoves at $40 \mathrm{~kW}$ : (a) staple food stove $A$; (b) staple food stove B, (c) subsidiary food stove C.

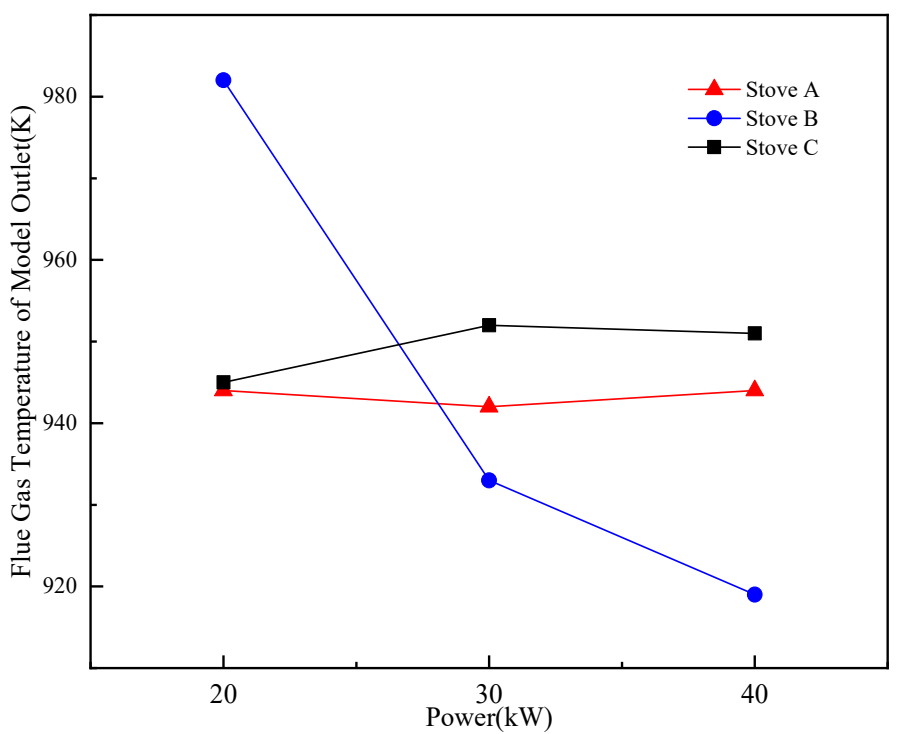

Figure 14. Flue gas temperature of the model outlet of the three stoves at different power rates.

\subsection{Comprehensive Analysis of Fuel Oil Cooking Stove}

Considering the above five indexes, which are interrelated and influence each other, there is no case in which each parameter is optimal at the same time. The simulation results of thermal efficiency, heat transfer intensity, heat flux uniformity, $\mathrm{CO}$ emissions, and flue gas temperature at the outlet of the model are normalized as $\mathrm{K}_{1}, \mathrm{~K}_{2}, \mathrm{~K}_{3}, \mathrm{~K}_{4}$, and $\mathrm{K}_{5}$ to 
form a performance pentagon, in order to comprehensively and intuitively compare the performance of different cooking stoves. The normalization method of the simulation results is as follows:

$$
\mathrm{K}_{\mathrm{i}}=\left[\mathrm{k}_{\mathrm{i}}-\min \left(\mathrm{k}_{\mathrm{i}}\right)\right] /\left[\max \left(\mathrm{k}_{\mathrm{i}}\right)-\min \left(\mathrm{k}_{\mathrm{i}}\right)\right]
$$

or

$$
\mathrm{K}_{\mathrm{i}}=\left[\max \left(\mathrm{k}_{\mathrm{i}}\right)-\mathrm{k}_{\mathrm{i}}\right] /\left[\max \left(\mathrm{k}_{\mathrm{i}}\right)-\min \left(\mathrm{k}_{\mathrm{i}}\right)\right]
$$

The results are shown in Figure 15. For the fuel oil cooking stove, a larger pentagon area implies better comprehensive performance. It is apparent that at $40 \mathrm{~kW}$ power, the heat transfer intensity of stove $\mathrm{C}$ is more prominent, which makes it exhibit the best comprehensive performance. At $30 \mathrm{~kW}$ and $20 \mathrm{~kW}$ power rates, the heat transfer intensity of stove $\mathrm{C}$ cannot be closely compared with stove $\mathrm{A}$, which presents a poor comprehensive performance than stove A. Despite this result, the main food stove B has good performance in the outlet flue gas temperature and heat flux uniformity, but other properties are worse, compared with stoves $\mathrm{A}$ and $\mathrm{C}$, resulting in its worst comprehensive performance and adaptability. When assembling the rotary burner, stove $\mathrm{A}$ has the best average performance at different power levels, while stove $\mathrm{C}$ has the best performance at higher power.

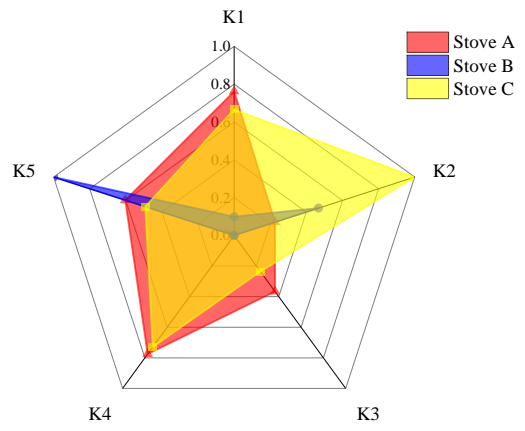

(a)

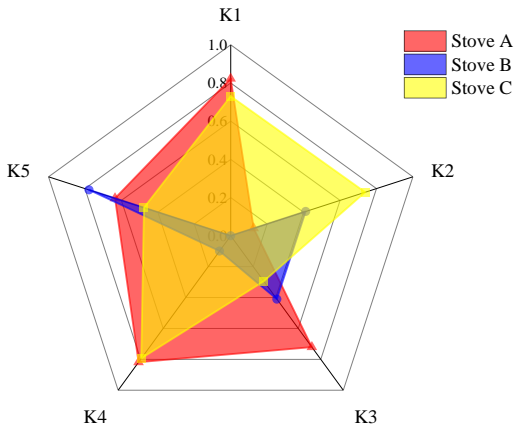

(b)

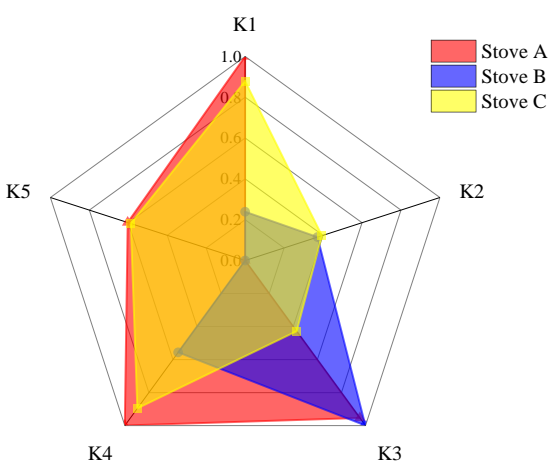

(c)

Figure 15. Performance pentagon of three stoves at different power rates: (a) $40 \mathrm{~kW}$; (b) $30 \mathrm{~kW}$; (c) $20 \mathrm{~kW}$.

\section{Conclusions}

The performance of three kinds of vehicle-mounted cooking stoves equipped with a novel rotary cup burner was studied by using numerical evaluation method, including thermal efficiency, heat transfer intensity, heat flux uniformity, $\mathrm{CO}$ emissions, and flue gas temperature at the outlet of the model. The results are as follows:

1. The structure of the combustion chamber influences the performance of the heating system. In staple food stove A, the high vessel makes the flue gas transfer more heat to the stove, which increases the efficiency of the total system. In staple food stove B, a high fireboard increases the intensity of the reflux zone formed at the bottom of the 
vessel. Although it increases the heat transfer intensity of the bottom of the boiler, it leads to insufficient combustion and also increased $\mathrm{CO}$ production. As a result, the thermal efficiency of stove $\mathrm{A}$ is about $7 \%$ higher than that of stove $\mathrm{B}$.

2. Due to the structural differences of the subsidiary and staple food stoves, the total heat transfer intensity of subsidiary food stove $\mathrm{C}$ is about $30 \%$ higher than the other two staple food stoves. The performance of thermal efficiency, $\mathrm{CO}$ emissions, and flue gas temperature at the outlet of the modeled subsidiary food stove $\mathrm{C}$ are slightly worse than those of staple food stove A.

3. The results of the five performance parameters were normalized to obtain the performance pentagon for a comprehensive evaluation, and it is found that the rotary cup burner has good adaptability to stoves A and C. Stove A has the best average performance at different power levels, while stove $C$ has the best performance at higher power. Since the single performance index, $K_{i}$, of stove B has the minimum value several times, its comprehensive performance is significantly worse than that of stoves $\mathrm{A}$ and stove $\mathrm{C}$.

Author Contributions: Conceptualization, Y.S. and H.L.; data curation, Y.S., H.L. and L.H.; formal analysis, Y.S. and L.H.; investigation, H.L. and L.H.; project administration, Y.S. and J.X.; supervision, Y.S. and J.X.; validation, Y.S. and J.X.; writing-original draft preparation, Y.S., H.L. and L.H.; writingreview and editing, Y.S., H.L., L.H. and J.X. All authors have read and agreed to the published version of the manuscript.

Funding: This research received no external funding.

Institutional Review Board Statement: Not applicable.

Informed Consent Statement: Not applicable.

Data Availability Statement: The data presented in this study are available on request from the corresponding author. The data are not publicly available due to data that forms part of an ongoing study.

Acknowledgments: The assistance from the State Key Laboratory of Coal Combustion, Huazhong University of Science and Technology is highly acknowledged.

Conflicts of Interest: The authors declare no conflict of interest.

\section{Nomenclature}

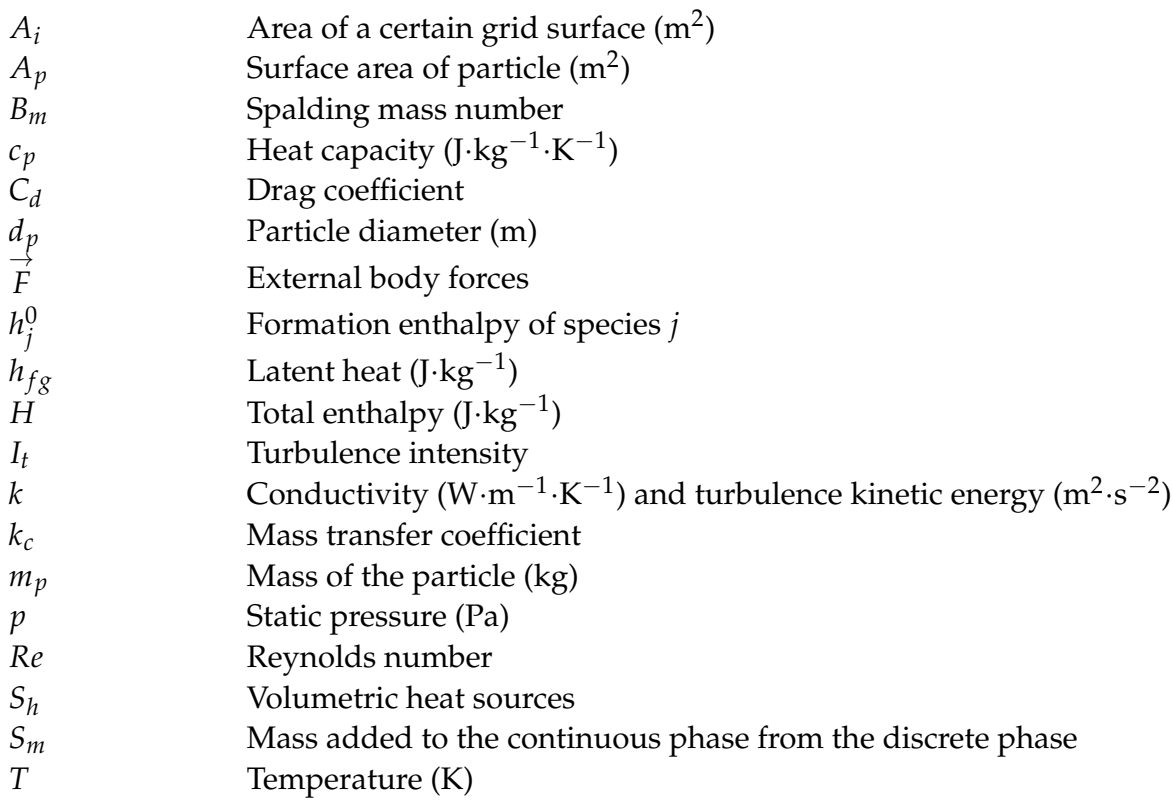




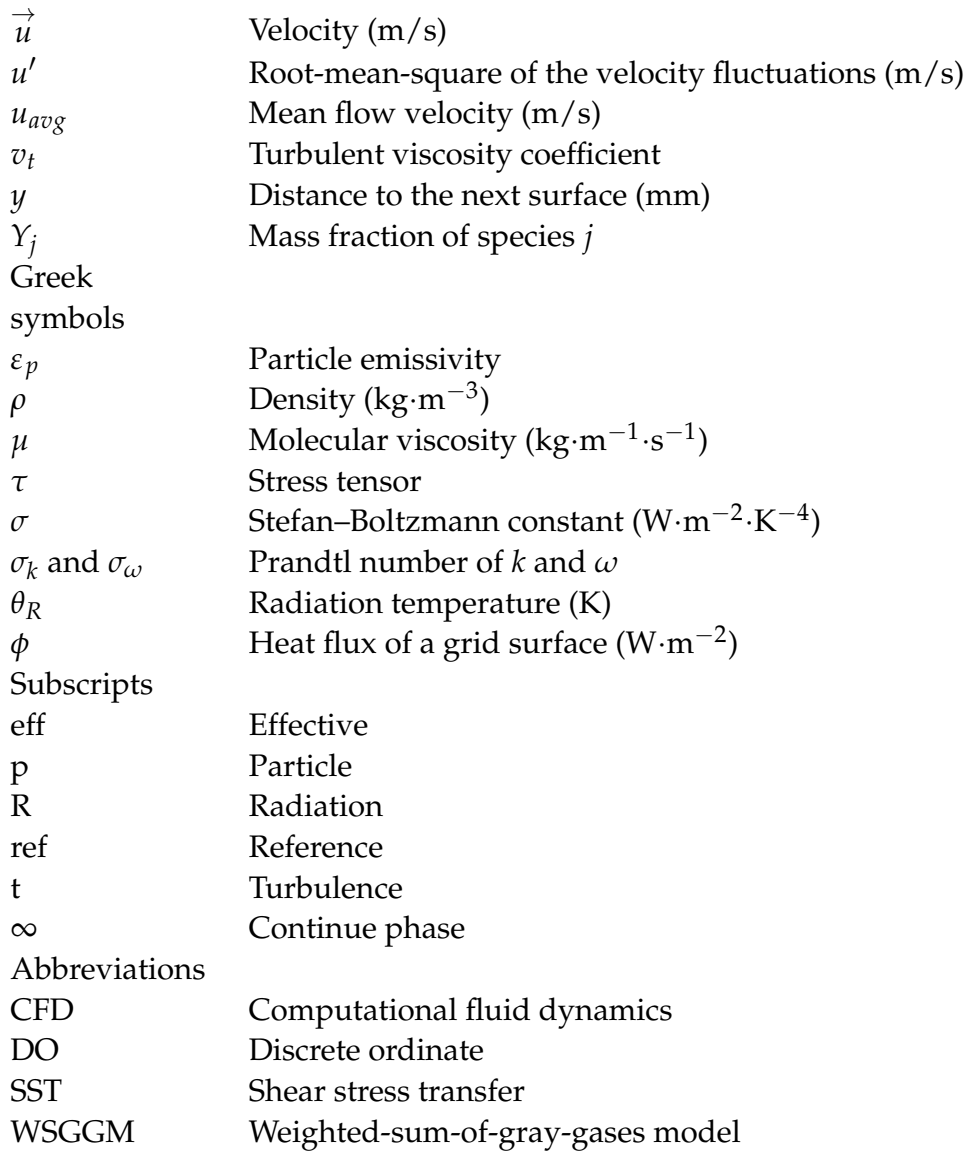

\section{References}

1. Jedelský, J.; Jícha, M. Spray characteristics and liquid distribution of multi-hole effervescent atomisers for industrial burners. Appl. Therm. Eng. 2016, 96, 286-296. [CrossRef]

2. Yao, S.; Zhang, J.; Fang, T. Effect of viscosities on structure and instability of sprays from a swirl atomizer. Exp. Therm. Fluid Sci. 2012, 39, 158-166. [CrossRef]

3. Vengatesh, P.; Raghu, P.; Nallusamy, N. Spray Characteristics of Diesel Fuel Using Numerical Simulation. Int. Res. J. Eng. Technol. 2018, 5, 1074-1077.

4. San José, J.; Sanz-Tejedor, M.A.; Arroyo, Y. Spray Characteristics, Combustion Performance, and Palm Oil Emissions in a Low-Pressure Auxiliary Air Fluid Pulverization Burner. Energy Fuels 2018, 32, 11502-11510. [CrossRef]

5. Alsulami, R.; Windell, B.; Nates, S.; Wang, W.; Won, S.H.; Windom, B. Investigating the role of atomization on flame stability of liquid fuels in an annular spray burner. Fuel 2020, 265, 116945. [CrossRef]

6. Hadef, R.; Lenze, B. Effects of co-and counter-swirl on the droplet characteristics in a spray flame. Chem. Eng. Processing: Process Intensif. 2008, 47, 2209-2217. [CrossRef]

7. Linck, M.; Armani, M.; Gupta, A. Flow Characteristic Effects on Flow Dynamics and Exhaust Gas Composition in Kerosene Spray Flames. In Proceedings of the 1st International Energy Conversion Engineering Conference (IECEC), Portsmouth, VA, USA, 17-21 August 2003; p. 5929.

8. Chong, C.T.; Hochgreb, S. Measurements of non-reacting and reacting flow fields of a liquid swirl flame burner. Chin. J. Mech. Eng. 2015, 28, 394-401. [CrossRef]

9. Presser, C.; Gupta, A.K.; Semerjian, H.G. Aerodynamic characteristics of swirling spray flames: Pressure-jet atomizer. Combust. Flame 1993, 92, 25-44. [CrossRef]

10. Wang, Y.; Xiang, J.; Su, S. Numerical simulation study of a typical low-NOx swirl burner. In Proceedings of the 4th International Green Energy Conference, Beijing, China, 19-23 October 2008; pp. 1164-1172.

11. Shum-Kivan, F.; Santiago, J.M.; Verdier, A.; Riber, E.; Renou, B.; Cabot, G.; Cuenot, B. Experimental and numerical analysis of a turbulent spray flame structure. Proc. Combust. Inst. 2017, 36, 2567-2575. [CrossRef]

12. Xie, K.; Cui, Y.; Qiu, X.; Wang, J. Experimental investigation on horizontal jet spray flame characteristics with a constant air-fuel ratio in different sub-atmospheric pressures. Appl. Therm. Eng. 2020, 165, 114555. [CrossRef]

13. Xie, K.; Qiu, X.Q.; Cui, Y.J. Experimental study on flame morphology of horizontal jet spray combustion in low pressure environment. Ind. Heat. 2018, 47, 8-12. 
14. Karami, S.; Hawkes, E.R.; Talei, M.; Chen, J.H. Edge flame structure in a turbulent lifted flame: A direct numerical simulation study. Combust. Flame 2016, 169, 110-128. [CrossRef]

15. Morcos, V.H.; Abdel-Rahim, Y.M. Parametric study of flame length characteristics in straight and swirl light-fuel oil burners. Fuel 1999, 78, 979-985. [CrossRef]

16. Datta, A.; Som, S.K. Effects of spray characteristics on combustion performance of a liquid fuel spray in a gas turbine combustor. Int. J. Energy Res. 1999, 23, 217-228. [CrossRef]

17. Bonefačić, I.; Wolf, I.; Blecich, P. Improvement of fuel oil spray combustion inside a $7 \mathrm{MW}$ industrial furnace: A numerical study Appl. Therm. Eng. 2017, 110, 795-804. [CrossRef]

18. Arkhipov, V.A.; Matvienko, O.V.; Trofimov, V.F. Combustion of sprayed liquid fuel in a swirling flow. Combust. Explos. Shock. Waves 2005, 41, 140-150. [CrossRef]

19. Xie, K.; Zhang, J.; Qin, C.; Tan, X.; Cui, Y. Numerical study on flame and emission characteristics of a small flue gas self-circulation diesel burner with different spray cone angles. Therm. Sci. 2021, 150. [CrossRef]

20. Li, X.; Cheng, Y.; Ji, S.; Lan, X. Influence of Key Structural Parameters of Combustion Chamber on the Performance of Diesel Engine. J. Energy Resour. Technol. 2017, 139, 042203. [CrossRef]

21. Musavi, Z.S.; Kusar, H.; Andersson, R.; Engvall, K. Modelling and optimization of a small diesel burner for mobile applications Energies 2018, 11, 2904. [CrossRef]

22. Zhou, H.; Li, X.; Zhao, W.; Liu, F. Effects of separated swirl combustion chamber geometries on the combustion and emission characteristics of DI diesel engines. Fuel 2019, 253, 488-500. [CrossRef]

23. Liu, J.; Zhang, Y.; Wang, Y.; Chen, L.; Xu, Y.; Zhao, H. Temperature distribution simulation and structural optimization of low-temperature combustion chamber in carbonization furnace. Chem. Ind. Eng. Prog. 2013, 32, $2112-2119$.

24. Su, S.; Xiang, J.; Sun, L.S.; Zhang, Z.X.; Sun, X.X.; Zheng, C.G. Numerical simulation of nitric oxide destruction by gaseous fuel reburning in a single-burner furnace. Proc. Combust. Inst. 2007, 31, 2795-2803. [CrossRef]

25. Xie, K.; Cui, Y.; Qiu, X.; Wang, J. Experimental study on flame characteristics and air entrainment of diesel horizontal spray burners at two different atmospheric pressures. Energy 2020, 211, 118906. [CrossRef]

26. Ogasawara, S.; Daikoku, M.; Shirota, M.; Inamura, T.; Saito, Y.; Yasumura, K.; Shoji, M.; Aoki, H.; Miura, T. Liquid atomization using a rotary bell cup atomizer (Influence of flow characteristics of liquid on breakup pattern). J. Fluid Sci. Technol. 2010, 5, 464-474. [CrossRef]

27. Panneton, B. Geometry and performance of a rotary cup atomizer. Appl. Eng. Agric. 2002, 18, 435. [CrossRef]

28. Viti, V.; Kulkarni, J.; Watve, A. Computational fluid dynamics analysis of the electrostatic spray painting process with a rotating bell cup. At. Sprays 2010, 20,1-17. [CrossRef]

29. Domnick, J.; Thieme, M. Atomization characteristics of high-speed rotary bell atomizers. At. Sprays 2006, 16, 857-874. [CrossRef]

30. Igari, N.; Iso, T.; Nishio, Y.; Izawa, S.; Fukunishi, Y. Numerical simulation of droplet-formation in rotary atomizer. Theor. Appl. Mech. Lett. 2019, 9, 202-205. [CrossRef]

31. Soma, T.; Katayama, T.; Tanimoto, J.; Saito, Y.; Matsushita, Y.; Aoki, H.; Nakai, D.; Kitamura, G.; Miura, M.; Asakawa, T.; et al. Liquid film flow on a high speed rotary bell-cup atomizer. Int. J. Multiph. Flow 2015, 70, 96-103. [CrossRef]

32. Sengupta, A.; Mukherjee, R.; Mishra, V.K. Performance and emission characteristic of burners: A review. AIP Conf. Proc. 2021, $2341,030027$.

33. Morsi, S.A.; Alexander, A.J. An investigation of particle trajectories in two-phase flow systems. J. Fluid Mech. 1972, 55, 193-208. [CrossRef]

34. Miller, R.S.; Harstad, K.; Bellan, J. Evaluation of equilibrium and non-equilibrium evaporation models for many-droplet gas-liquid flow simulations. Int. J. Multiph. Flow 1998, 24, 1025-1055. [CrossRef]

35. Sazhin, S.S. Advanced models of fuel droplet heating and evaporation. Prog. Energy Combust. Sci. 2006, 32, 162-214. [CrossRef] 